\title{
有機七素系農薬の合成とその開発 および企業化
}

長 沢 正 雄*

I. 緒言

\section{研究の動機ならびにヒ素剂の歴史}

戦後, DDT, パラチオンを始めとする外国䢅薬技術が 続々と導入され，警異的な成果と共に急速に普及され， 合成有機䢅薬による農業栽培技術の革新がもたらされた のである。私共も贯薬生産技術に携る者として, 製剤技 術より脱却して独自の新農薬創製を夢みたのであるが, そのためには如何なる化合物を合成し, どのような方法 手段によりスクリーニングを行ない，目的の病害虫に対 し有効な新化合物を見出したらよいかを定めねばならな い。しかも采統的に薬物と生物効果との関係を追求する 必要がある。化学療法郕においては, 偶然性はつきもの であるとしても，一つの筋を通した研究を行なうこと は, 今後の研究のためにも貴重な手がかりとなるからで ある。化学構造と薬理作用 (薬効, 薬害) に関する研究 に当り，私共は有機七素化合物をその手段として選ん だ。その主な理由は次の通りである。(1)他の毒物に比し 医薬面から多くの研究がなされておりながら, 農薬面で は完全に未開発分野であること (2)合成法も開拓されて いるので; 化学構造と薬効との関係を系統的に追求する 手段として好都合であること (3)資源的に豊富かつ安価 に入手できること (4)生物活性の可能性が大きいこと。

次にヒ素剤の歷史を簡単に述べよう。無機七素化合物 の歴史は古く, 1867 年 Makham によりパリスグリー ン (Paris-green) の殺虫性が見出されて以来, 今日の ヒ酸鉛に至るまで殺虫郕の重要な地位を占めてきたので あり，その中毒原因はグルタチオンの正常な作用を阻害 するためといわれる。しかし有機七素化合物 ${ }^{1 \sim 3)}$ の殺虫 性についての研究は少なく Riedeberg らが, Arsenomethane As-1,2-disulfide $\left(\mathrm{CH}_{3}-\mathrm{As}-\mathrm{As}-\mathrm{CH}_{3}\right)$ につい $\mathrm{S} \stackrel{\text { II }}{\mathrm{S}}$

て薬害があるが数種の昆虫に殺虫力を有することを紹介 しているのが注目されるにすぎない(1952 年)。次に殺菌 性 ${ }^{4,5)}$ に関しても若干の報告はあるが, 農業病害菌につ

\footnotetext{
* イハラ榓薬株式会社（東京都千代田区九段2-1)
}

いて体系的に報告されたものは見当らない。ただ Leukel らにより Methyl Arsine Sulfide が種子伝染性の 小麦黒穂病に消毒力があることを報告している位であっ た(1952 年)。少なくとも私共が研究着手した昭和 28 年 （1953）当時には，実用的有機七素系農薬は，文献上を 市販製品も見られなかったといってよい情況であった。 医薬における化学療法剤は 1910 年 Ehrlich, 奏による Arsenobenzol の創製に始まるといわれる。

七素系化学療法剂恃大別して @Arsenobenzene 系 (1)Arsinoxide 系, @Arsonic Acid 系に分類されるが， その生体内に拄ける作用本体は Arsinoxide と考光られ ている ${ }^{6,7,8)}$ 。また七素剂には人体毒性の大きいものもあ

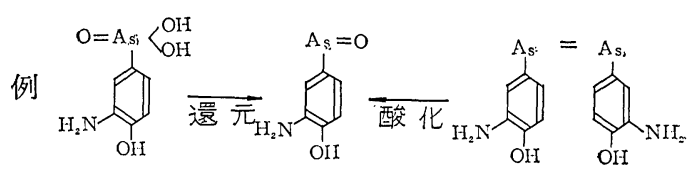

るが，水銀剤に比すれば排泄が迅速で蓄積されることも 少なく, 解毒機構も解明され BAL 等の秀れた解毒剤も 知られている。

このように化学構造と薬理作用の検討がなさているこ とは，他部門への応用に際し好都合ではあるが，医薬と してすぐれた療法剤であっても農薬として利用する場合 は，対称病原体はもとより使用法も使用環境も異なり， 必要条件は根本的に相異しているわけである。したがっ て全く新たな角度からの生物検定による化学構造との関 係を吟味する必要があるわけである。

\section{II. 有機七素化合物の合成}

As は週期律表 $\mathrm{Vb}$ 族 ( $\mathrm{P}, \mathrm{As}, \mathrm{Sb}, \mathrm{Bi})$ 亿属する。原 子を構成する電子配列の点では As は $\mathrm{N}, \mathrm{P}$ 亿類似して いるため, 表 1 の如く想定される形式の化合物はほと んど存在する。

含七素官能基が Arsonic Acid, Arsenic Acid, Arsine Oxide, Arsinehalide, Cycloarsine 等, 非常に多様性を 示し，その上それらの化合物が互変性を有しており，同、 
表 1 有機ヒ素化合物の基本誘導体

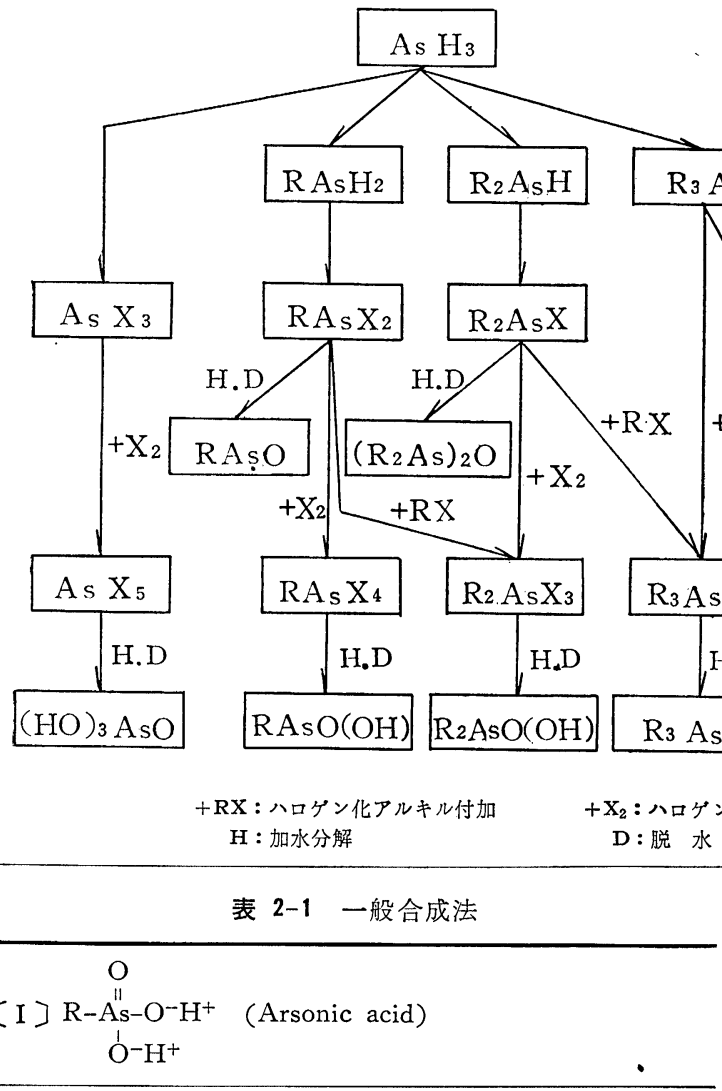

(a) Meyer's Reaction (R : Alkyl) $\mathrm{O}^{-} \mathrm{Na}^{+} . \mathrm{O} \mathrm{NaI}^{-}$

$\mathrm{H}_{3} \mathrm{CI}+:$ As- $-\mathrm{O}^{-} \mathrm{Na}^{+} \rightarrow \mathrm{H}_{3} \mathrm{CAs}^{\prime}-\mathrm{O}^{-} \mathrm{Na}^{+} \rightarrow \mathrm{H}_{3} \mathrm{CAs}-\mathrm{O}^{\prime \prime} \mathrm{Na}^{+}$ $\stackrel{\mathrm{O}}{-} \mathrm{Na}^{+} \stackrel{\mathrm{O}-\mathrm{Na}^{+}}{{ }^{+}} \mathrm{O}^{-} \mathrm{Na}^{+}$

(b) Bart's Reaction (R:Aryl)

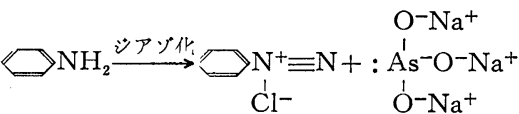

$\rightarrow \underset{\substack{\mathrm{O} \\ \mathrm{A}}}{\stackrel{\mathrm{O}}{\mathrm{O}} \mathrm{O}^{-} \mathrm{Na}^{+}} \mathrm{Na}^{+}$

$\Longleftrightarrow \mathrm{N}^{+} \equiv \mathrm{N} \cdot \mathrm{FeCl}_{3}+\mathrm{AsCl}_{3}+\mathrm{Fe} \longrightarrow \longrightarrow \mathrm{As}_{\backslash \mathrm{Cl}} \mathrm{Cl}$ $\mathrm{Cl}^{-}$

$\bigotimes \mathrm{As}{ }_{\mathrm{Cl}}^{\mathrm{Cl}}+2 \mathrm{HNO}_{3} \longrightarrow \underset{\substack{\mathrm{O} \\ \mathrm{O}^{\prime}-\mathrm{H}^{+}}}{\mathrm{As}^{-}-\mathrm{H}^{+}}$

(c) Bechamp's Reaction<smiles>O=[As](O)(O)(O)CCCOc1ccc(O)cc1</smiles>

一分子内でもCの作用機能との不 干渉をもっていること，すなわち 一つの化合物中で As と C の官能 基の両方に独立して置換し得る点 は，有機ヒ素化合物の複雑性を示 すものである。既知の有機金属化 合物の中で As はその数と多様性 において他の追随を許さぬものが あるともいえる。しかし私共は農 薬への利用を主目的とするため, 一般に既知方法を採用した。

1. 一般合成法 ${ }^{9,10)}$ 構造多 様の原因は官能基を形成する能力 の大きいためであるが，ここでは 基本的 Functional group の Arsonic Acid, Arsinic Acid につい て概説する。(表 2-1,2-2)

2. 分類 有機七素化合物の 分類は便宜上 (I ) 脂肪族系, (II) 芳香族系 (III) 複素環式化合物系

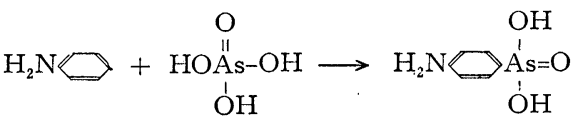

(d) Rosenmund Method.

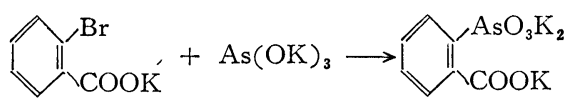

表 2-2 一 般合成 法

$$
\mathrm{O}
$$

[II] $\mathrm{R}-\mathrm{A}_{\mathrm{s}}-\mathrm{O}^{-} \mathrm{H}^{+}$(Arsinic acid) $\mathrm{R}$

(a) Quick \& Adam's Redction (R: Alkyl)

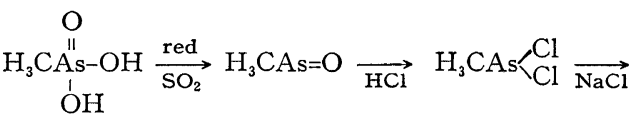

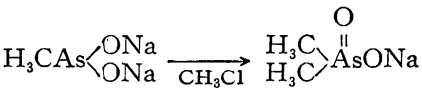

(b) Bart's Reaction 改良法

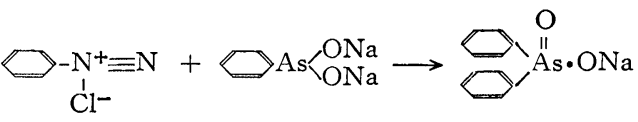

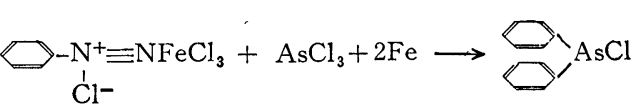




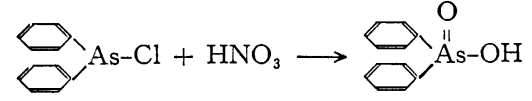

表 3 有機七素化合物の分類

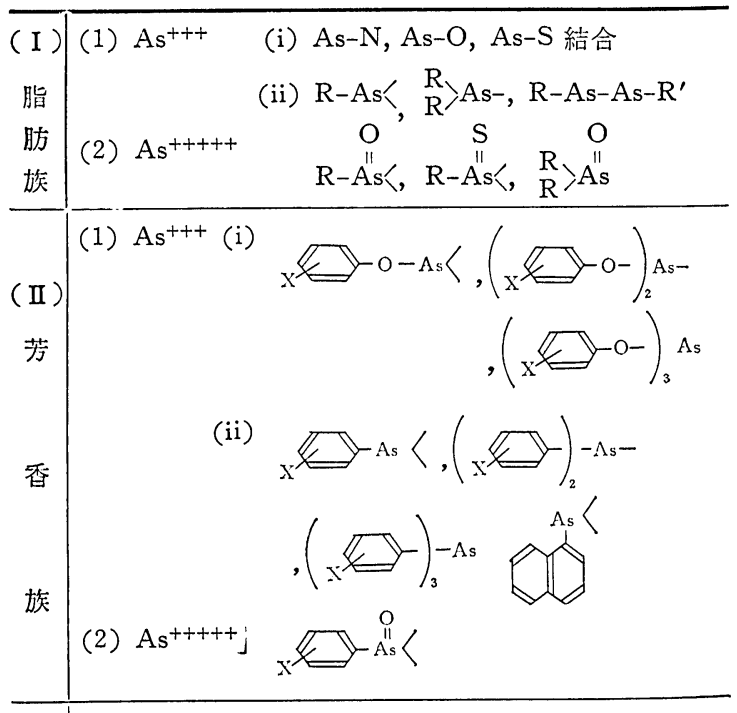

(1) Hetero-As

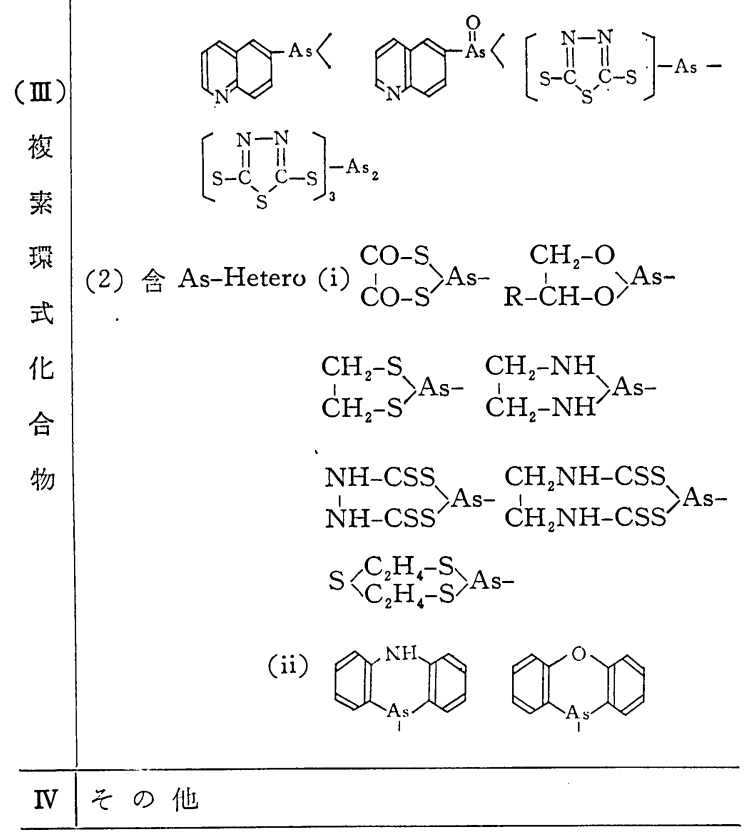

(Heterocyclic) (IV) その他に大別して, 直接 As-C の 結合をたないものは区別し，また As が 3 洒と 5 価のも のも区別して生物効果を判定した。（表 3）

\section{III. 化学構造亡生物効果亡の関係}

1. 殺虫性 As が P と同族であることおよび無機 七素剤の殺虫性から鑑みて, 有機七素化合物は食毒性, 接触毒性を兼備し，リン剂に代り得べき性質を保持する ものと期待して, 構造別に接触殺虫力を主とした検定を 行なった。その結果は一般に接触毒性は低く, 含リンヒ 素化合物を除けばわずかに Alkyl-As=S がDDT 級の効 果を示したに過ぎず，殺虫剤として実用化の可能性を認 め得なかった。(成績省略)

2. 殺菌性 他面若干の化合物は殺菌力が強大で, 水銀化合物に匹敵することから，イモチ病防除に散布し たところ, 偶然にも, 不十分ながら本病よりはむしろ紋 枯病に特異的作用を示すことが認められた。当時（昭和 28年）紋枯病は適切な防除薬剂もなく, 早期栽培の普及 と相まって重要問題となりつつあった。そこで研究重点 を紋枯病に設定してまずスクリーニング方法の吟味から 着手したのである。いうまでもなく化学療法剤研究にお いて最も重要な点は, 如何にして適切な生物検定法を採 用するかにあり，“スクリーニング法を考案した者が勝 者である”とさえ極言されている。私共はまず(1)抗菌ス ペクトラムを求め, 次に(2)イモチ病菌を用いて胞子発芽 阻止力 (LD-90) を測定し, これより化学構造と直接的 殺菌力との関係を解明せんとした。しかし紋枯病に対し ては, 直接殺菌力と野外効果との相関はきわめて低く, 適切な検定法の必要を痛感した。私は予俑的に若干の化 合物を用い，本病に対する数種の生物検定法を吟味した ところ, そら豆葉法 (高坂氏法 ${ }^{11}$ ) ) が実験材料, 処理, 結果の判定ならびに作用性の検討の上から好都合である ばかりでなく, 野外効果とも最も相関が高いことを知っ た。また作用面から(1菌糸伸長阻止力, (1菌系侵入阻止 力 (保護効果), 病斑の 進展阻止力 (治療効果) にわ けて考察することは至当と思われるが，野外効果を確実 にするためには, 化合物の安定性, 残効性と共に侵入阻 止力の大なること，すなわち “低濃度における保護効 果”が重要因子であることを想定した。（表 4）

以上のことを背景とし全化合物について，直接殺菌力 ならびにそら豆葉法による侵入阻止力検定の二面より， 薬効と構造との関係を追求し，有効化合物若干を選抜し 得た。(表 $5,6,7$ )私共は当初複雑なあるいは特殊な構造に ひかれたがバイエルのヒ素刜 $\left[\mathrm{CH}_{3}-\mathrm{As}\left(\mathrm{S}-\stackrel{\mathrm{S}}{\mathrm{S}-\mathrm{N}}{ }^{\prime}\left(\mathrm{CH}_{3}\right)_{2}\right]\right.$ が発表され奇しくも B-153 と同一であることを知って より，in Vivo における有効構造の本体即ち単純化に努 めた。その結果 R-As<の中でも，すべての検定法に合 格せる $\mathrm{B}-312\left(\mathrm{CH}_{3}-\mathrm{As}=\mathrm{S}\right)$ とさらには直接的殺菌力は 
表 4 各種殺菌郕の作用性比較 紋枯病に対する勃果の解析 （高坂氏による）

\begin{tabular}{|c|c|c|c|c|c|c|c|}
\hline \multirow[b]{2}{*}{ 薬 剂 名 } & \multicolumn{2}{|c|}{\begin{tabular}{|l|} 
菌糸伸長 \\
抑制作用 \\
\end{tabular}} & \multicolumn{2}{|c|}{$\begin{array}{l}\text { 侵入防止 } \\
\text { 作用* } \\
\end{array}$} & \multicolumn{3}{|c|}{$\begin{array}{l}\text { 病斑部に於ける菌 } \\
\text { 糸形成阻止作用** }\end{array}$} \\
\hline & $\begin{array}{l}\text { スライ } \\
\text { ド上 }\end{array}$ & \begin{tabular}{|l|} 
寄主体 \\
上
\end{tabular} & $\begin{array}{l}\text { 侵入防 } \\
\text { 止力 }\end{array}$ & 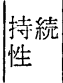 & \begin{tabular}{|l} 
菌系形 \\
成阻止 \\
力
\end{tabular} & \begin{tabular}{|l} 
病斑拡 \\
大阻止
\end{tabular} & 持続性 \\
\hline ボルド & \pm & \pm & HWH & H⿻川⿲丶丶丶㇒木 & - & - & \\
\hline $\begin{array}{l}\text { 塩基性 } \\
\text { 塩化銅 }\end{array}$ & \pm & \pm & HWI & HWH & - & - & \\
\hline PMA & H & H & \pm & & \pm & \pm & \\
\hline EMP & HHH & HW & $H$ & + & HHH & HHAt & + \\
\hline $\mathrm{PMF}$ & HHt & H & \pm & & + & + & \\
\hline 七素剂 & HWH & H⿻川 & H州 & 曲 & HiH & thitit & 冊 \\
\hline
\end{tabular}

（参考表）水稲の病害虫による被害量

\begin{tabular}{c|c|c|c|c}
\hline 区 & 分 \\
年 病害虫 \\
次
\end{tabular}

表 5 有機ヒ素化合物の殺菌特性の一例

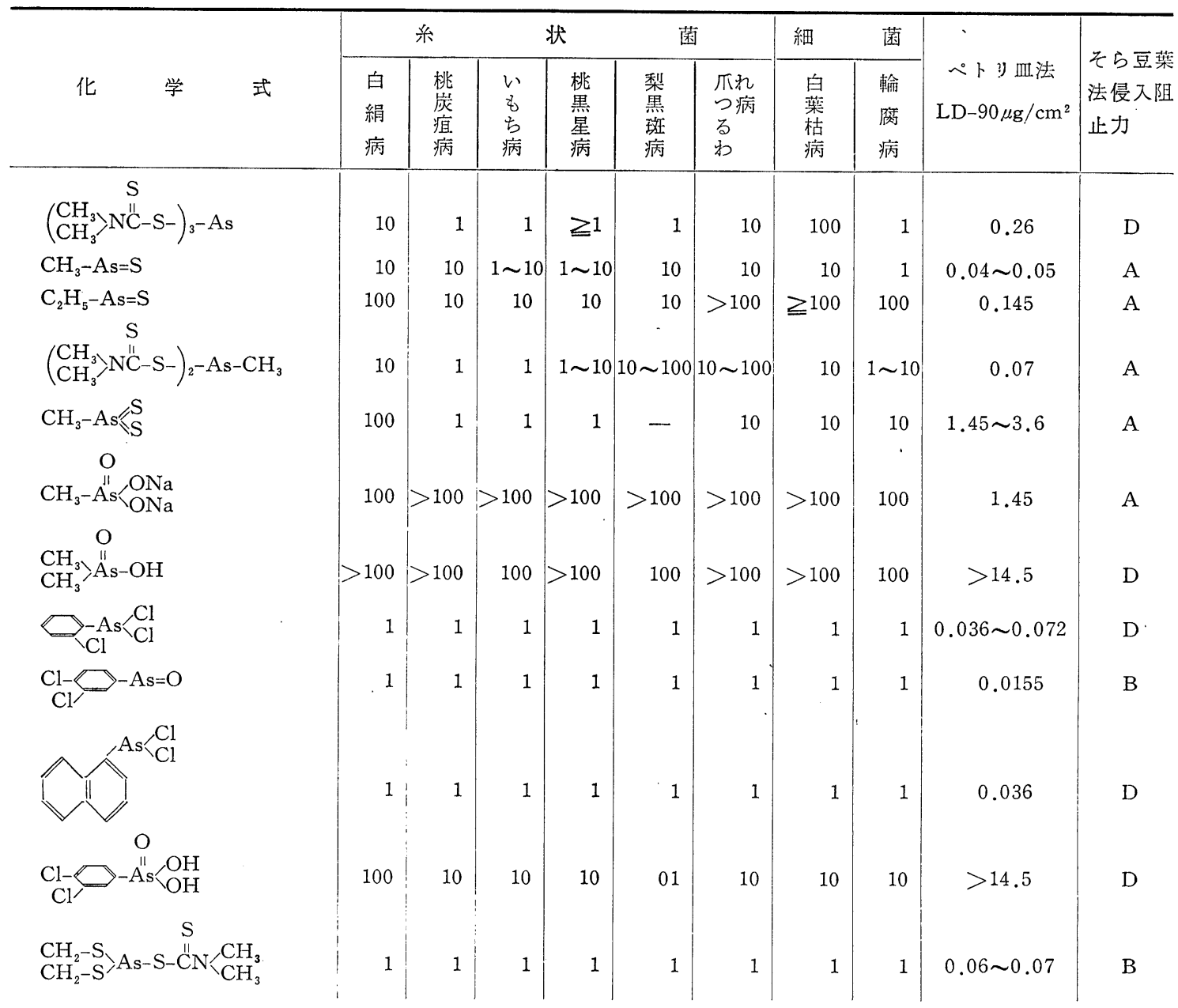




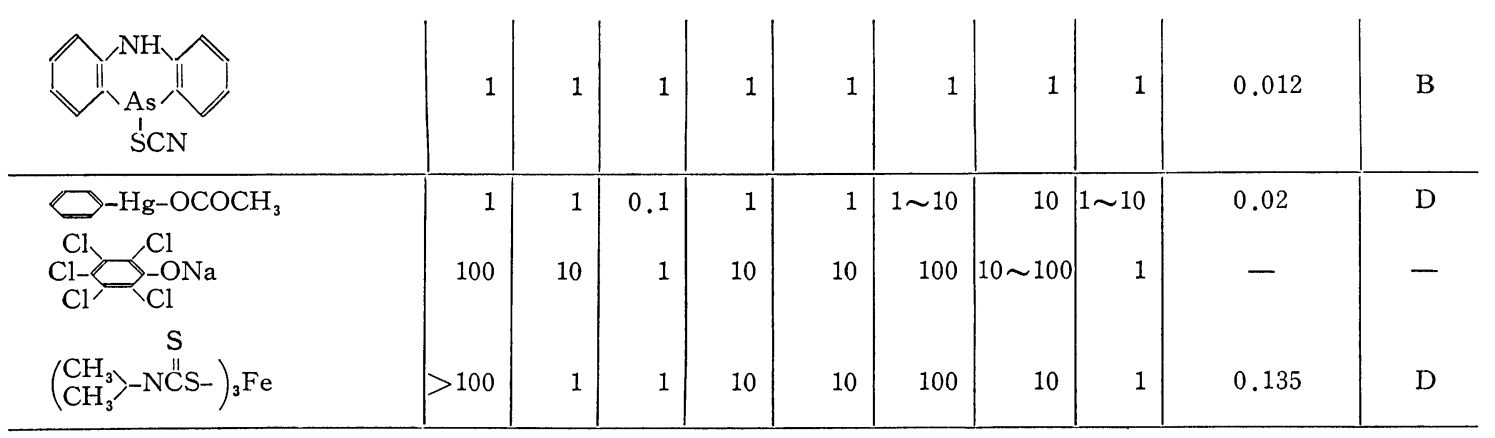

表 6 基本構造別の勃果分類

in vitro $と$ in vivoの殺菌性の差

\begin{tabular}{|c|c|c|c|c|c|c|c|c|c|c|c|c|c|}
\hline \multirow{2}{*}{\multicolumn{3}{|c|}{ 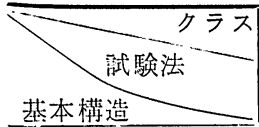 }} & \multicolumn{2}{|c|}{ A } & \multicolumn{2}{|c|}{ B } & \multicolumn{3}{|c|}{ C } & \multicolumn{2}{|c|}{ D } & \multicolumn{2}{|c|}{ 計 } \\
\hline & & & & & I & & I & & II & & II & I & II \\
\hline 脂 & 肪 & 族 & & 13 & 8 & 4 & 11 & & 81 & 9 & 16 & 41 & 41 \\
\hline 芳 & 香 & 族 & 10 & & 14 & 5 & 4 & & 3 & 0 & 30 & 38 & 38 \\
\hline 複 & 蓀 & 環 & 19 & & 14 & 11 & $\mathrm{~g}$ & 1 & 1 & 8 & 27 & 50 & 50 \\
\hline & 部 & & & 14 & 36 & 20 & 4 & 2 & & 7 & & 29 & 129 \\
\hline
\end{tabular}

I : 胞子発芽阻止力..............in Vitro

II : 侵入阻止力 (とら豆葉法) ……in Vivo

表 7 紋枯病に対する構造別の有効化合物例 (一次撰抜)

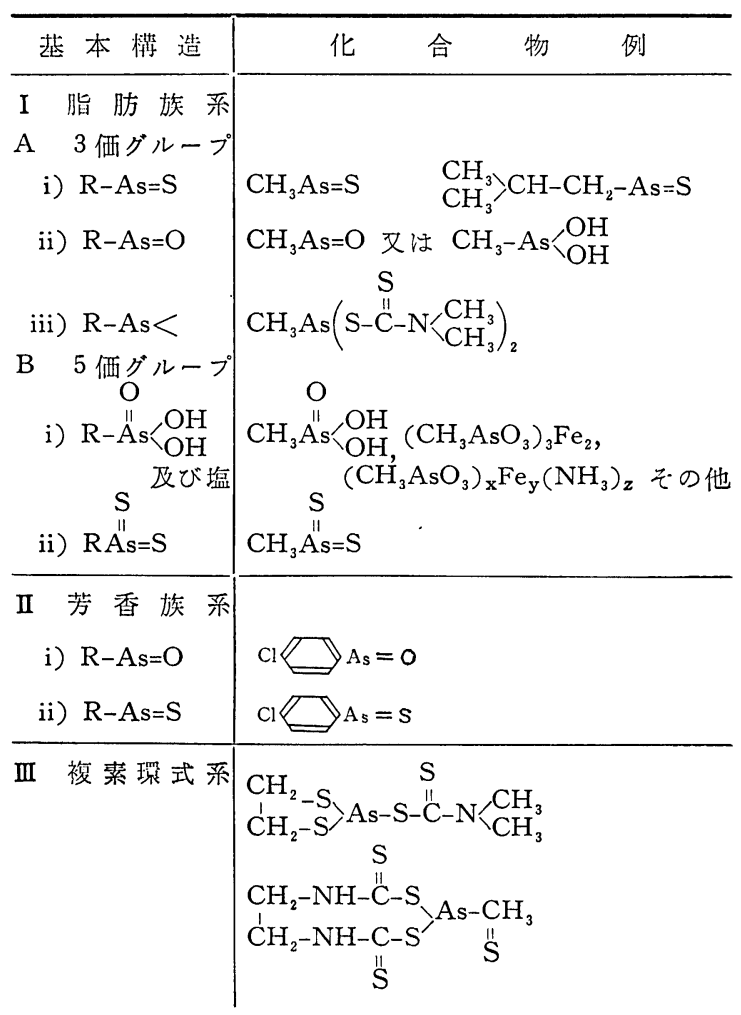

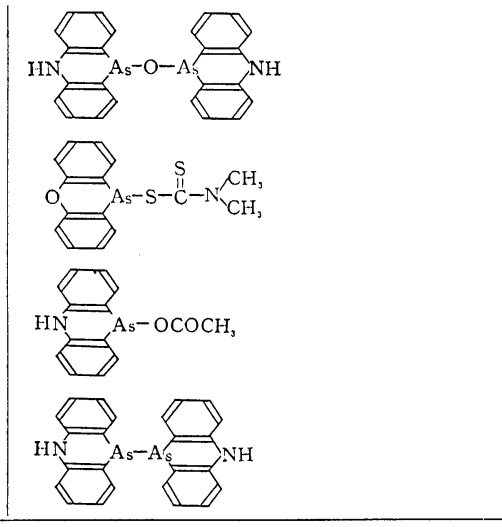

ないが,植物体上で特異的に卓効を示す B-287 $\left(\mathrm{C}^{-} \mathrm{H}_{3}-\mathrm{A}\right.$ (OH $\mathrm{OH}$ ) とその塩を撰定し得たのである。しかも両者の殺 菌特性はきわめて優れ, 野外試験においても総ての供試 薬剤中最も有効な成績を示したのである。（科学の目的 は Simplify にあることを新たに痛感させられたしだい である。)

化学構造と殺菌性との関係を取まとめれば次の通りで ある。(1)一般に優れた殺菌性を有するものが多いが菌に 対する撰択性は少ない。(2)概して 3 価化合物は 5 価化合 物に比して殺菌力が大きい。(3) As が直接Cに結合して いない場合および化学的に不安定な化合物は一般に殺菌 力が小さい。(4)附加基，置換基の影響は直接殺菌力にお いて見られるが，生体上では余り大きいものではない。 (5)直接殺菌力は基本構造別には, 芳香族系>複素環式系 >脂肪族系であった。6植物体上での侵入阻止力（保護 効果) は必ずしも直接殺菌力と平行せず, 基本構造別に も, 脂肪族系 $>$ 複素環式系 $>$ 芳香族系と反対の傾向を示 した。(7)紋枯病に対して, Alkyl-As＜誘導体は特効薬 的作用を発揮する。(8)脂肪族アルソン酸 $(\mathrm{R}-\mathrm{A} \stackrel{\mathrm{O}}{\text { ॥ }}<\mathrm{OH}$ OH びその塩は, 生体上においては特異的に卓効を発現する が,これは強い移行性 (Systemic Action) を有し, 生 
$\mathrm{O}$

体内で還元され $\mathrm{R}-\mathrm{As} \backslash \mathrm{OH} \longrightarrow \mathrm{OH}-\mathrm{Os}=\mathrm{O}$ となり作用す ると推定される。したがって医薬において Phenyl-As= Oが作用の本体であると考えられているのと対称的であ る。(9稲紋枯病に in vivo で最も有効な構造は Alkyl一 $\mathrm{As}<$ であるが，簡単な $\mathrm{CH}_{3}-\mathrm{As}=\mathrm{S}, \mathrm{CH}_{3}-\mathrm{A}^{\Perp} \leq \mathrm{OH}$ で十分 であるばかりか最大の効果を有する。したがって生体内 での有効作用構造は Alk-As=S, Alk-As=O, と推論す る。

3. 殺菌剤としての実用化 次に有機上素剂共通の 欠点として,稲の稔実阻害が指摘されたが金属塩特に $\mathrm{Fe}$ 塩の作用は薬効を低下させることなく完全に不榆現象を 防止することを見出した。この薬害軽減剤の発見は有機 七素剂の実用化に重要な意義をもつものである。(表 8)

表 8 植物薬害軽減効果の一例

\begin{tabular}{|c|c|c|}
\hline 供 試 薬 剂 & 稔 実 率 & 穂重 率 \\
\hline 処 & $100 \%$ & $100 \%$ \\
\hline$※ \mathrm{CH}_{3} \mathrm{As}=\mathrm{S}$ 単 用 & $22 \%$ & $33 \%$ \\
\hline$+\mathrm{Fe}^{++}$加 用 & 100 & 102 \\
\hline$+Z_{n}++$ 加 用 & 87 & 73 \\
\hline$+\mathrm{Mg}^{++}$加 用 & 8 & 21 \\
\hline + BO--- 加用 & 36 & 42 \\
\hline$※ \mathrm{CH}_{3} \mathrm{As}^{\mathrm{O}} \backslash \mathrm{ONa}$ 算用 & 0 & 3 \\
\hline$+\mathrm{FeSO}_{4}$ 加用 & 99 & 95 \\
\hline$+\mathrm{Cr}\left(\mathrm{SO}_{4}\right)_{3}$ 加用 & 99 & 103 \\
\hline$+\mathrm{CuSO}_{4}$ 加用 & 0 & 10 \\
\hline$+\mathrm{Ca}\left(\mathrm{NO}_{3}\right)_{2}$ 加用 & 0 & 2 \\
\hline
\end{tabular}

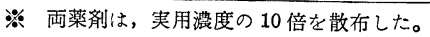

薬害軽減機構に関しては不明の点が多いが, 従来の可溶 性七素が原因であるとする説は, $\left(\mathrm{CH}_{3} \mathrm{AsO}_{3}\right)_{\mathbf{x}} \cdot \mathrm{Fe}_{\mathbf{y}}$ ・ $\left(\mathrm{NH}_{3}\right)_{z}$ の如く水溶性塩でも害作用の発現が見られない ことからみて不当と考える。生体内での As 金属と酵素 との関係および $\mathrm{Fe}, \mathrm{Cr}, \mathrm{Zn}, \mathrm{Mg}, \mathrm{K}$ 等の金属イオンと稔 実との関係を生理的に明らかにした上で，結論を下した い。

最近ブドー晚應病に有効なことおよび $\left(\begin{array}{l}\mathrm{CH}_{3} \\ \mathrm{CH}_{3}>\mathrm{N}-\mathrm{C}-\mathrm{C}\end{array}\right.$ ・As が蔬菜のウドンコ病に卓効を示すことが判明し，利 用面も搪大されつつある。またこれらの薬剤は人体毒 性, 魚毒共に小さく農薬としての具備条件を満足するむ のである。

最後に, 生物試験の結果, 実用化を決定せる前記化合
物については，工業的諸条件（合成打よびに製郕上）の 決定に際し，かなりの問題点があったが省略する。唯， 粉剂は $0.15 \sim 0.4 \%$ の有効成分を含む微粉のため, 表 面上で酸化等の経時的変化を受け易く, 合成とは逆に, $\mathrm{R}-\mathrm{As} \mathrm{s}_{\mathrm{X}}^{\mathrm{X}}(\mathrm{I}) \longrightarrow \mathrm{R}-\mathrm{A}^{\mathrm{I}} \mathrm{S} \backslash \mathrm{OH}$ (II) に戻るため, 安定 な製剤として一般にアルソン酸 (II) の塩が利用される 様になった。生体内変化と考え合せ興味梁いものがあ る。

なお Methyl Arsine Sulfide に関しては, 従来 $\mathrm{CH}_{3}$ $\mathrm{As}=\mathrm{S}$ として記載されているが, Kary および Riedeberg 等の報告した Arsenomethane-As-1,2-disulfide $\left(\begin{array}{c}\mathrm{CH}_{3}-\mathrm{As}_{\mathrm{N}}=\mathrm{As}_{\mathrm{S}}-\mathrm{CH}_{3} \\ \mathrm{~S}\end{array}\right)$ の合成法が類似していることから疑 問を抱き比較検討した。その結果, 両者は同一物質で, 3 価七素化合物であると認定した。さらにその分子量, 双極子能率等の測定結果㧍よび他の類似構造物質より推 定し，環状構造とするのが正しいと考えられる。ここに Methyl Arsine Sulfide の化学構造として次式すなわ ち表 9 のを提案したい。(表 9)<smiles>C[As]1S[As](C)S[As](C)S1</smiles>

(4)

表 $9 \quad(R-A s=S)_{n}$ の推定構造式<smiles>C[As]1S[As](C)S[As](C)S1</smiles>

[II] 近似構造<smiles>CB1OB(C)OB(C)O1</smiles>

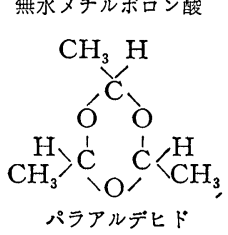<smiles>CC1(C)SC(C)(C)SC(C)(C)S1</smiles>

トリチオアセトン<smiles>C1CSCSCS1</smiles> 
4. 殺草性 構造との関係は概略の傾向を明らかに したが，なお検即すべき問題が多く残されている。しか し殺草性の高い化合物も多数見受けられるので, 将来は 非農耕地向除草剂として十分活用される可能 性があろ 5.

\section{IV. 結語}

以上，有機七素化合物の農薬への利用を目的とし，そ の系統的合成と, 化学構造と薬理作用特に殺菌性に関す る研究の概略を述べた。目的上, 合成に当っては一般に 既知の方法を採用し, 有機合成化学上の内容に乏しいこ とをお詑びする。省みて企業化まで 6〜7 年を要しなが ら，結論的には最も簡単な物質に帰結したことを思う時 生物防除剤の難しさは別としても，化学者として深く恥 ずるしだいである。しかし今後の農薬研究開発に多少な りとも凟するところあれば望外の喜びである。

本研究は多数の先輩, 関係者のご指導ご協力により始 めて成し得たものであり，この機会に衷必よりの謝意を 表したい。また，本日受賞の栄と講演の機会を与えられ た本協会関係の皆様に厚くお礼申上げて, 結びと致しま
す。

$$
\text { 文献 }
$$

イハラ㕮薬研究報告（特別報告第一号）の“有機七菜 化合物の䂝薬への利用に関する研究”を参照されたい。

1) Y.F. Hsing, J. Econ. Ent. 40883 (1947)

2) T. Riedeberg, Agr. Chem. 752 (1952)

3) D.E. Jack et al., J.Econ. Ent. 49239 (1956)

4) R.W. Leukel, Plant Disease Repts 36 426 (1952)

5) E.Urbshaft, Chem. Abst. 485879 (1954)

6) 豊島，最新の化学療法郕(1953)

7) T. Ueda, S. Toyoshima, Pharm. Bull. 1 (1953)

8) T. Ueda, S. Toyoshima, ibid. 2 (1954)

9) F.G. Rochow et al., The Chem. of Org.Compds 198 (1957)

10) 熊田, 大有機化学 18296 (1957)

11) 高坂, 植物防疫 10331 (1956)

12）長沢，山本他，日植病報 2416 (1959)

13) 長沢, 山本他, ibid. 2427 (1959)

14) 長沢, 山本他 ibid. 2530 (1959)

15）長沢他，日本特許 $230,110236,349 \quad 236,350$ $236,351 \quad 237,100 \quad 243,607 \quad 243,608 \quad 247,152$ $247,889 \quad 247,890 \quad 249,464 \quad 249,851 \quad 258,383$. $256,411 \quad 257,875 \quad 257,876 \quad 260,104$

\section{次号予 定}

総説

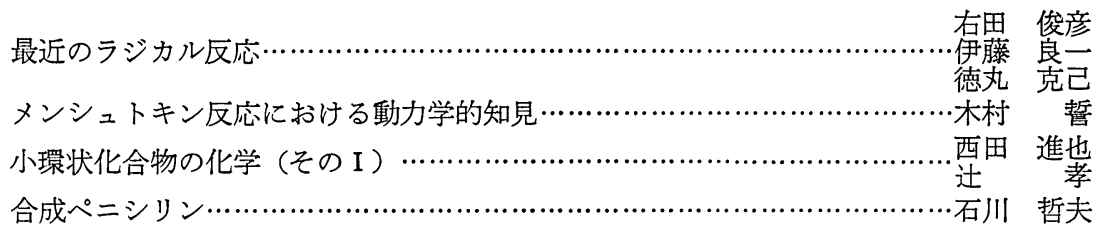

報文

脂肪族ジアミンの合成に関する研究（第 1 報） 木村 午朗, 他

同

上（第 2 報） 木村 午朗, 他

\section{業界情勢}

抗生物質工業界の展望. 八木沢行正

文献紹介 